\title{
ГИДРОГЕОЛОГИЯ
}

\section{Гидрогеологическая характеристика разреза Аракаевской параметрической скважины}

\author{
Г.Л. Беляева \\ ОАО «КамНИИКИГС», 614016, Пермь, ул. Краснофлотская, 15 \\ E-mail: belka61@inbox.ru \\ (Статья поступила в редакиию 20 апреля 2015 г.)
}

\begin{abstract}
Установлены границы гидрогеологических этажей и глубины залегания водоносных комплексов в разрезе Аракаевской параметрической скважины. Различными методами определен гидрохимический состав подземных вод. Учитывая большое число надвиговых дислокаций, осложняющих разрез, в комплексах выделены аллохтонные и автохтонные водовмещающие толщи.

Ключевые слова: водоносный комплекс, поровые воды, буровой раствор, водовмещиююуая толща.
\end{abstract}

DOI: $10.17072 /$ psu.geol.27.26

В гидрогеологическом отношении участок Западно-Уральской складчатонадвиговой зоны, где пробурена Аракаевская параметрическая скважина, находится в Западно-Уральском районе подземных вод Предуральского сложного бассейна пластовых (блоково-пластовых) вод. Восточная граница ЗападноУральского района подземных вод проведена по восточной границе распространения пермских отложений, что обосновывается разной степенью литификации, а следовательно, и типом скопления подземных вод в пермских (Предуралье) и каменноугольных (Урал) отложениях [1].

Гидрогеологические комплексы рассматриваемой территории совпадают с тектоническими этажами, разделенными поверхностями углового и стратиграфического несогласия, надвигами, толщами слабопроницаемых и непроницаемых по- род. Формированию современного тектонического строения осадочный комплекс рассматриваемой территории обязан позднегерцинским и альпийским тектоническим движениям, которые оказывали активное влияние и на гидродинамические условия водоносных комплексов.

Для района бурения Аракаевской параметрической скважины, как и для Западно-Уральской складчато-надвиговой зоны в целом, гидрогеологическая зональность и параметры пластовых вод различных стратиграфических подразделений характеризуются наличием сложных гидродинамических условий. С учетом литологических особенностей водовмещающих пород, наличия флюидоупорных глинисто-карбонатных толщ и особенностей гидрогеохимического разреза осадочных пород снизу вверх в районе бурения выделены следующие водонос- 
ные комплексы (ВК): додевонский или рифейско-вендский терригенно-карбонатный; эмсско-тиманский или нижнесреднедевонский терригенный; верхнедевонско-турнейский карбонатный; визейский терригенный, визейско-башкирский карбонатный; московский карбонатнотерригенный водоносно-водоупорный комплекс; верхнекаменноугольный карбонатный; нижнепермский сульфатнокарбонатно-терригенный ВК, четвертичный ВК [2]. Указанная последовательность ВК в скважине осложнена рядом надвиговых дислокаций, по причине которых в комплексах выделены аллохтонные и автохтонные водовмещающие толщи (рисунок).

При рассмотрении гидрогеологических условий разреза Аракаевской параметрической скважины использованы результаты бурения и опробований, гидрогеохимических исследований буровых растворов и промывочной жидкости, гидрохимических и гидродинамических исследований скважин района бурения, а также печатные и фондовые материалы, посвященные гидрогеологическим исследованиям Западно-Уральской складчатонадвиговой зоны.

В процессе гидрогеологических исследований гидрохимическая зональность разреза установлена в основном косвенными гидрогеохимическими методами: изучением химического состава поровых вод (водных экстрактов пород) и фильтратов буровых растворов. Всего по разрезу скважины изучено две пробы пластовой воды, 40 проб фильтратов бурового раствора и 35 проб водных экстрактов.

\section{Додевонский или рифейско-} вендский терригенно-карбонатный ВК в районе бурения скважины и на прилегающих территориях ранее не изучался. Он сложен мощной толщей осадочных пород рифейского и вендского возраста и представлен конгломератами, песчаниками, известняками, доломитами, алевролитами и аргиллитами преимущественно розоватого цвета. Считается, что воды находятся в условиях застойного водного ре- жима, благоприятного для формирования и сохранения залежей углеводородов [3].

Вскрытый Аракаевской скважиной додевонский ВК представлен в интервале 4930-5207 м толщей осадочных пород рифейского и вендского возраста, сложенной полимиктовыми песчаниками и алевролитами с прослоями аргиллитов. При проходке данного интервала использовался карбонатный буровой раствор с добавлением реагентов, содержащих в своем составе $\mathrm{Na}^{+}\left(\mathrm{KМЦ-1100,} \mathrm{Na}_{2} \mathrm{CO}_{3}\right)$ и карбонаты, в т.ч. известь, что необходимо учитывать при исследовании химического состава фильтрата бурового раствора. Интерпретация результатов анализа фильтрата позволяет сделать предположение о хлоридно-натриевом составе пластовых вод. Поровые воды хлоридные натриевые, характеризуются щелочной реакцией среды $(\mathrm{pH}=10)$. В целом воды рифейсковендского комплекса элизионные, отжаты под влиянием давления и температуры в водопроницаемые слои песчаников и алевролитов.

Эмсско-тиманский (нижне-среднедевонский) терригенный ВК объединяет водонефтенасыщенные породы от венда до тиманского горизонта среднего девона. Это толща преимущественно терригенных пород с небольшими прослойками карбонатов и глинисто-карбонатных отложений. Воды комплекса вскрыты в зоне застойного режима на расположенной рядом Бухаровской площади в интервале 4036-4166 м. Вода по основным гидрохимическим показателям близка к водам отложений терригенного девона, высокое содержание $\mathrm{HBO}_{2}$ может быть связано с внедрением вод нижнепермского комплекса при эпейрогенических движениях.

В Аракаевской скважине этот комплекс представлен отложениями тиманского горизонта в интервале 4900-4930 м (см. рисунок) и сложен карбонатными породами (известняками, доломитами, мергелями) с песчаниками в верхней части.

Воды верхнедевонско-турнейского карбонатного ВК на прилегающих территориях характеризуются повышенным 


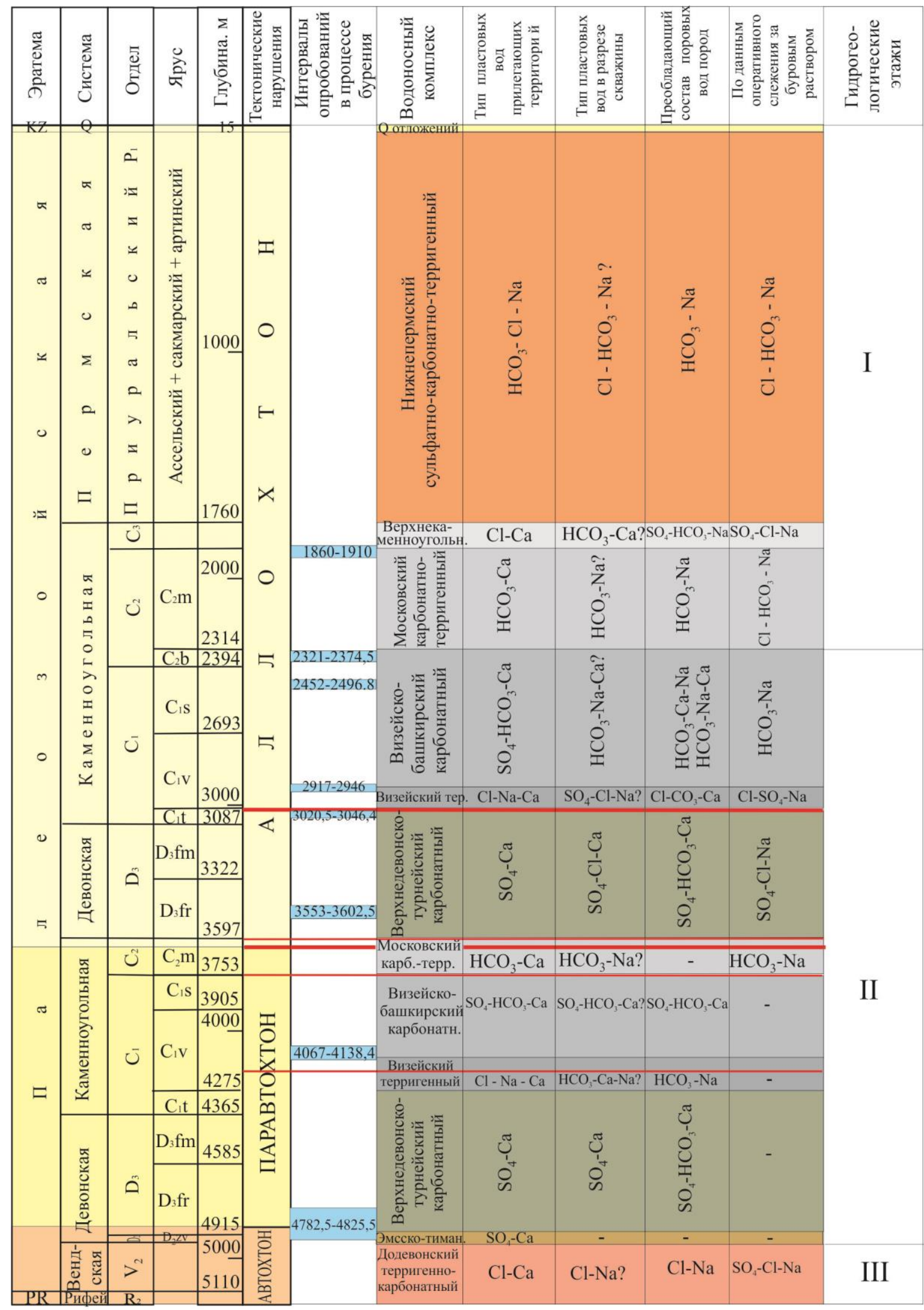

Гидрогеологический разрез Аракаевской скважины 
содержанием сульфат-ионов. Данный ВК вскрыт скважиной дважды: в интервале 4275-4900 м в паравтохтоне и в аллохтоне в интервале 3013-3597 м. Паравтохтонная, более глубинная часть комплекса, представлена доломитизированными известняками, доломитами и мергелями франско-фаменского возраста и турнейскими известняками, верхним флюидоупором являются косьвинские аргиллиты. На такой глубине верхнедевонско-турнейский ВК вскрыт впервые.

Поровые воды паравтохтонного интервала комплекса исследовались в интервале 4614,3-4818,22 м. Очень высокая сульфатность вод $\left(\mathrm{SO}_{4}{ }^{2-}=40-99 \%\right)$ характерна для зон разрушения нефтяных залежей, особенно на больших глубинах, где из-за высоких температур окислительная агрессивность сульфатов возрастает. Однако данные выводы в большей степени правомочны для пластовых вод, а не для поровых. Кроме того, ангидритовокарбонатный состав вмещающих пород также оказывает значительное влияние на высокое содержание сульфат-ионов в водных экстрактах пород.

Воды открытых пор, извлеченные из доломитовой толщи того же возраста, перекрывающей ангидритово-карбонатную, имеют открытую пористость 0,74-2,99 \%, pH 8,2-8,8. Повышенная сульфатность вод сохраняется $\left(\mathrm{SO}_{4}{ }^{2-}=29-42 \%\right)$, но значительно возрастает доля гидрокарбонатиона $\left(\mathrm{HCO}_{3}{ }^{-}=27-60 \%\right)$.

Состав пластовых вод паравтохтонной части комплекса с большой долей вероятности сульфатно-кальциевый, что в целом соответствует составу подземных вод верхнедевонско-турнейского ВК данной территории [2].

Выше по разрезу в интервале 30193597 м карбонатные отложения верхнедевонско-турнейского водоносного комплекса, ограниченные сверху верхнетурнейскими (косьвинскими) аргиллитами, снизу - швом надвига, встречены повторно в аллохтоне, в самой нижней его части. Опробованный при проходке скважины интервал 3020,5-3046,4 м представлен во- донасыщенными мелкозернистыми трещиноватыми известняками турнейского возраста. Пластовые воды имеют плотность 1,157-1,158 г/дм³ ${ }^{3}$ соленые на вкус. Содержание сульфат-иона составляет 0,81-0,84 г/дм ${ }^{3}$, что в два раза ниже, чем в водах данного комплекса в зонах разгрузки. По результатам исследований воды отнесены к хлоридному кальциевому типу. Общая минерализация составила 221,9 $г /$ дм $^{3}, \mathrm{pH}=6,06-6,07$.

В интервале 3553-3602,5 м при аналогичном опробовании франской части этого же ВК получен приток газированной смеси пластового флюида с сильным запахом УВ и жидкости из подпакерного пространства общим объемом 100 л. Минерализация полученного флюида составила $16,5-17,54$ г/дм ${ }^{3}$, состав сульфатнохлоридно-кальциевый. По сравнению с паравтохтонным блоком в пластовых водах аллохтонной части наблюдалось высокое содержание хлорид-ионов (до 5400 мг/дм $\left.{ }^{3}\right)$.

Визейский терригенный ВК объединяет водонефтенасыщенные породы терригенных отложений визейского яруса нижнего карбона, мощность которых на рассматриваемой территории не превышает 100 м. Флюидоупором в кровле служат глинистые известняки тульского горизонта, а в подошве - глинистые и окремнелые турнейские известняки или аргиллиты косьвинского горизонта. Воды в зоне активного водообмена (Западный склон Урала) обогащены кальцием и почти не содержат сульфатов [2]. Об исследовании вод визейского терригенного ВК в зоне затрудненного и застойного водообмена (глубже 500 м) сведений нет.

Визейский терригенный ВК вскрыт скважиной в аллохтонной (2920-3013 м) и в паравтохтонной (4121-4275 м) частях разреза. Кроме того, в паравтохтонной части комплекса наблюдается сдвоение разреза: визейская терригенная толща повторяется дважды, разделенная швом надвига на глубине 4189 м. За счет этого мощность визейского терригенного ВК в паравтохтоне увеличена по сравнению с 
аллохтоном. Подошвенным водоупором комплекса служат верхнетурнейские (косьвинские) аргиллиты, в кровле ВК водоупор представлен глинистыми известняками нижней толщи верхневизейского подъяруса.

Поровые воды терригенных пород паравтохтона низкоминерализованные $\left(0,09\right.$ г/дм $\left.{ }^{3}\right)$, гидрокарбонатно-натриевые, с повышенным содержанием магния (до 19 \% мас. на породу). Это самая высокая концентрация магния из всех исследованных водных экстрактов Аракаевской скважины.

В экстрактах водных растворов пород зоны надвигового шва (4180-4189,5 м) количество гидрокарбонат-ионов резко возрастает до $86 \%$, доля сульфат- и хлоридионов падает соответственно до 9 и 5 \%. В катионном составе по-прежнему преобладает натрий (58\%), но количество кальция возрастает до $40 \%, \mathrm{Mg}^{2+}=2 \%$.

Поровые воды визейской аллохтонной терригенной толщи имеют щелочную реакцию среды $(\mathrm{pH}=10,05)$, минерализация составляет $0,17 \%$ масс. на породу. В анионном составе большое количество хлорид- и карбонат-ионов (по $35 \%$ ), среди катионов резко доминирует $\mathrm{Na}^{+}-93 \%$.

В процессе испытания аллохтонной части комплекса зафиксирован интенсивный выход горючего газа из труб с выбросом флюида над запорным клапаном. Coстав флюида (смеси пластовой и технической воды) сульфатный натриевый с повышенным содержанием $\mathrm{Cl}^{-}$. Газ углеводородный, содержание метана 93-96 \%.

Визейско-башкирский карбонатный ВК объединяет карбонатные породы визейского (окский надгоризонт), серпуховского и башкирского ярусов карбона. На прилегающих территориях отложения характеризуются закарстованностью, а также общностью химического состава и сходными гидродинамическими условиями. Данная толща пород в целом характеризуется наличием трещинно-карстовых коллекторов и изучалась ранее преимущественно как водонефтевмещающая, пер- спективная для получения притоков нефти.

Визейско-башкирский карбонатный ВК в Аракаевской скважине также встречен и в аллохтоне, и в паравтохтоне. В интервале 3753-4122 м паравтохтона башкирская часть комплекса отсутствует, а визейские породы интенсивно доломитизированы, сульфатизированы, разбиты тектоническими швами и оперяющими их трещинами. В поровых водах визейских карбонатов в анионном составе преобладает $\mathrm{HCO}_{3}{ }^{-}(57 \%)$, меньше $\mathrm{SO}_{4}{ }^{2-}(34 \%)$. Среди катионов доминирует $\mathrm{Ca}^{2+}(59 \%)$.

Выше по разрезу комплекс вскрыт в аллохтоне в интервале 2314-2920 м. Вмещающие породы представлены известняками с прослоями доломитов и мергелей. Опробование серпуховских отложений в интервале 2452-2496,8 м установило наличие УВ газа метанового состава. Визейские карбонаты в интервале 2672-2902 м характеризуются поровыми водами с $\mathrm{pH}=8,05-9,7$ и минерализацией $\mathrm{M}=0,05$ 0,066 \% масс. на породу. В целом поровые воды визейской аллохтонной карбонатной толщи гидрокарбонатные и карбонатные, кальциево-натриевые и натриевокальциевые.

Состав поровых вод вышележащих серпуховских доломитов от визейских карбонатных пород отличается более высоким содержанием хлорид-иона (до 48 \%), по составу воды преимущественно гидрокарбонатные и карбонатные, кальциево-натриевые и натриево-кальциевые.

В целом пластовые воды визейскобашкирского ВК, исследованные в аллохтонной и паравтохтонной частях разреза только косвенными методами, можно охарактеризовать как преимущественно гидрокарбонатные, натриево-кальциевые и кальциево-натриевые.

Московский карбонатно-терригенный водоносно-водоупорный комплекс (ВВК) объединяет водонасыщенные пласты карбонатно-терригенных отложений московского яруса. Комплекс опробован на Бухаровской площади, где он присутствует в объеме подольского и мячковско- 
го горизонтов среднего карбона. При испытании газонасыщенных мячковских пород установлено высокое содержание водорастворенного сероводорода (до 1000 мг/дм $\left.{ }^{3}\right)$.

Московский ВВК в аллохтонной части разреза Аракаевской скважины сдвоенный: в верхней части он пройден в интервале 1867-2314 м и представлен породами московского яруса в полном объеме, преимущественно известняками, часто окремнелыми, с прослоями аргиллитов. В подошве комплекса залегают плотные алевролиты, прослоями известковистые, перекрывается комплекс алевролитами и мергелями верхнего карбона.

Повторное появление вмещающих пород данного ВК в объеме только нижней части яруса (верейского подъяруса) отмечено ниже по разрезу в интервале 35973753 м. Здесь верейские отложения встречены дважды: между швами надвигов на отметках 3597 м и 3637 м при мощности нижнемосковской толщи 40 м и ниже шва основного надвига $(3637$ м) до глубины 3753 м, где зафиксировано сбросовое нарушение. Здесь мощность пород этого ВК составляет $116 \mathrm{~m}$.

Фильтраты бурового раствора, отобранные в процессе оперативного слежения за циклами бурения, характеризуются повышением минерализации от подачи раствора в скважину до выхода. Увеличение минерализации связано с повышением концентрации гидрокарбонат-ионов и ионов натрия, поступивших из пластовых вод гидрокарбонатного натриевого типа.

Верхнекаменноугольный карбонатный ВК в зоне западно-уральских складок экранирован плотными монолитными известняками и доломитами в кровле и подошве отдела и характеризуется гидродинамической зоной застойного режима. В разрезе скважины ВК представлен преимущественно флюидоупорной мергельно-алевролитовой толщей в интервале 1760-1867 м, экранирующей сверху московский карбонатно-терригенный ВВК. При опробовании в процессе бурения интервала 1860-1910 м получен приток го- рючего газа с последующим изливом жидкости сульфатно-хлоридно-натриевого состава под напором. Жидкость, скорее всего, является технической, газ преимущественно метановый $\left(93,8-94,6 \% \mathrm{CH}_{4}\right.$ в пересчете на безвоздушный).

Фильтрат бурового раствора, отобранный из интервала 1900,1-1901,2 м, характеризуется начальной общей минерализацией 11,4 г/дм ${ }^{3}$ и повышением ее до 11,6 г/дм ${ }^{3}$ на выходе. Увеличение минерализации связано с повышением концентрации гидрокарбонат-ионов и ионов кальция, поступивших из пластовых вод.

Нижнепермский сульфатно-карбонатно-терригенный ВК объединяет водонасыщенные пласты нижней перми (ассельские, сакмарские и артинские отложения) с общим падением на запад. Породы представлены в основном мергелями. Это самый верхний из изученных ВК Аракаевской скважины, залегающий на глубине 10-1760 м и представленный в полном объеме. Анализ водных экстрактов пород подтвердил довольно высокую минерализацию (до 0,1-0,2 \%) поровых вод гидрокарбонатно-натриевого состава, что близко к гидрокарбонатно-хлориднонатриевым пластовым водам артинских песчаников Бухаровской антиклинали [2].

Поровые воды аллохтонных отложений артинского возраста (интервал исследования 1494,4-1760 м) имеют щелочную реакцию среды $(\mathrm{pH}=8,82-10,65)$, минерализацию 0,11-0,27 \% масс. на породу. Анионный состав поровых растворов существенно различается. Повышенное содержание сульфат-иона (до 46 \%) зафиксировано на глубине 1815,8 м в мергелях, а в терригенных породах интервала 14941519 м доминируют карбонат- и гидроксил-ионы.

Фильтраты бурового раствора в наблюдаемых циклах бурения характеризуются повышением минерализации, связанной с увеличением концентрации гидрокарбонат- и хлорид-ионов, а также кальция и натрия. На основании анализов фильтратов бурового раствора можно 
сделать предположение о гидрокарбонатно-натриево-кальциевом составе пластовых вод нижнепермского сульфатнокарбонатно-терригенного ВК.

Водоносный комплекс четвертичных отложений при бурении скважины не изучался.

В целом вертикальная гидрохимическая зональность подземных вод в Западно-Уральской складчато-надвиговой зоне фактически не изучена. Анализ отрывочных данных по отдельным площадям (Бухаровская, Урминская) и различным водоносным комплексам [2] позволяет сделать вывод о том, что в зоне застойного водного режима отложения содержат в основном рассолы хлоридно-кальциевого типа. Характерной особенностью вод являются высокие содержания кальция (до 15-16 г/дм ${ }^{3}$ ) при минерализации рассолов до 183 г/дм ${ }^{3}$, воды также обогащены магнием, йодом, бромом, бором и аммонием. При складкообразовании и надвиговых тектонических движениях и вмещающие отложения, и подземные воды подвергались более интенсивному метаморфизму. Все поровые воды, полученные из образцов Аракаевской скважины, характеризуются очень низкой минерализацией (менее 5 г/дм $\left.{ }^{3}\right)$.

Осадочные породы зоны развития Предуральского сложного бассейна пластовых (блоково-пластовых) вод на одних участках разреза значительно уплотнены, на других рассланцованы, разбиты трещинами. Химический состав подземных вод по условиям метаморфизма и обогащения вод отдельными микрокомпонентами в целом близок к водам аналогичных комплексов, вскрытых на прилегающих территориях.

Анализируя гидрогеохимический разрез скважины, построенный на основании результатов преимущественно косвенных исследований, по анионному составу пластовых вод можно условно выделить три гидрогеологических этажа. Третий, самый нижний автохтонный этаж, представлен хлоридными водами додевонских отложений. Вышележащий гидрогеологический этаж преимущественно сульфатных вод объединяет эмсско-тиманский терригенный, верхнедевонско-турнейский карбонатный, визейский терригенный и визейско-башкирский карбонатный ВК и распространяется на верхнюю часть автохтона, весь паравтохтон и аллохтонную часть разреза до глубины 23214 м. Небольшой по мощности визейский терригенный ВК, входящий в выделенный этаж, встречается дважды и в обоих случаях приурочен к участкам тектонических нарушений. При опробовании визейского комплекса в интервале 2917-2946 м произошел выброс флюида сульфатно-натриевого состава, но воды нижележащей части комплекса определены как преимущественно гидрокарбонатные. Выявленные в разрезе скважины надвиги, сбросы и сопровождающие их зоны дробления и повышенной трещиноватости в период тектонической активности обеспечивали возможные перетоки пластовых вод между водоносными комплексами, а также изменение их гидрохимического состава за счет активизации вторичного минералообразования. Такие геологические процессы могли повлиять на состав пластовых вод визейского терригенного ВК и московского карбонатно-терригенного ВВК, попадающего нижним интервалом распространения во второй гидрогеологический этаж и приуроченного к зоне шва основного надвига (интервал 3597-3753 м).

Верхний, аллохтонный гидрогеологический этаж преимущественно гидрокарбонатных вод не осложнен тектоническими нарушениями и включает московский водоносно-водоупорный комплекс, а также верхнекаменноугольный и нижнепермский водоносные комплексы.

Формирование горных сооружений Урала оказало активное влияние на гидродинамику зоны сочленения передовых складок Западного Урала с восточным бортом Русской плиты. В настоящее время гидродинамической связи между этими территориями не прослеживается. Наличие многочисленных надвиговых структур и сбросов, а также сильно 
уплотненных пород затрудняет фильтрацию пластовых флюидов с Урала в сторону Предуральского краевого прогиба [2]. Однако в районах активных тектонических движений, особенно в узлах сочленения разнонаправленных трещин, создавались наиболее благоприятные условия для вертикальной миграции углеводородов.

\section{Библиографический список}

1. Перечень бассейнов подземных вод территории СССР для ведения Государствен- ного водного кадастра. М.: ВСЕГИНГЕО, $1988.146 \mathrm{c}$.

2. Шестов И.Н. и др. Анализ результатов испытания продуктивных отложений поисково-разведочных скважин Соликамской впадины и ПСУ с использованием гидрогеохимических критериев оценки перспектив нефтегазоносности / КамНИИКИГС. Пермь, 2003. 88 c.

3. Boдbl нефтяных и газовых месторождений СССР: справочник / под ред. Л.М. Зорькина. М.: Недра, 1989. 382 с.

\title{
Hydrogeologic Characteristic of Arakaevskaya Parametric Well
}

\author{
G.L. Belyaeva \\ JSC "KAMNIIKIGS", 15 Krasnoflotskaya Perm 614016, Russia \\ E-mail: belka61@inbox.ru
}

In the paper, the boundaries and depth of water-bearing units in the Arakaevskaya parametric well are established. The methods of aquifers hydro-chemical composition study and its results are described. Due to occurrence of overthrust structures at the observed area, the allochthon and autochthon water-bearing units are defined. Analysis of hydrodynamic regime showed that the interaction between Urals aquifers and those at the area of study is not observed.

Key words: water-bearing complex; pore water; mud; aquifer.

\section{References}

1. Perechen basseynov podzemnykh vod territorii SSSR dlya vedeniya Gosudarstvennogo vodnogo kadastra [List of underground water basins at the USSR territory for management of the State water register]. Moskva, VSEGINGEO, 1988, p. 146. (in Russian)

2. Shestov I.N. et al. 2003. Analiz rezultatov ispytaniya produktivnykh otlozheniy poiskovo-razvedochnykh skvazhin Solikamskoy vpadiny $\mathrm{i}$ PSU $\mathrm{s}$ ispolzovaniem gidroge- okhimicheskikh kriteriev otsenki perspektiv nefetgazonosnosti [Analysis of test results at productive sediments of Solikamskaya Basin and Urals Foreland Faults exploration boreholes using hydro-geochemical criteria of oil and gas potential assessment]. Perm, KamNIIKIGS, p. 88. (in Russian)

3. Vody neftyanykh i gazovykh mestorozhdeniy SSSR: Spravochnik [Waters of oil and gas deposits of USSR: Guidebook]. Ed. Zorkin L.M., Moskva, Nedra, 1989, p. 382. (in Russian) 